日平滑筋誌 (Jap. J. Smooth Muscle Res.) 2, 27-30, 1966.

\title{
ラット子宮筋内燐酸化合物の変動について
}

\author{
東京医科歯科大学医学部 産科婦人科学教窒 \\ (主任 藤井久四郎教授) \\ 加藤宏一，石田雅巳，丸岡利市
}

\section{STUDIES ON THE PHOSPHOROUS COMPOUNDS IN THE UTERINE MUSCLE OF RAT}

\author{
Koichi Kato, Masami Ishida and Toshiichi Maruoka \\ Department of Obstetrics and Gynecology, Tokyo Medical \\ and Dental University (Director: Prof. K. Fujii)
}

For the purpose of the investigation of the mechanism of the labour, the phosphorous compounds in the uterine muscle of rat were measured through each stage of pregnancy, parturition and weaning.

1) RNA-P and RNA-P/DNA-P ratio increased in pregnancy and showed the maximum value at the end stage of pregnancy, and then rapidly decreased in parturition.

Since ten days after parturition it began to approach to the value of non-pregnancy.

2) DNA-P increased in pregnancy and later on it remained approximately constant.

3) Acidsoluble $\mathrm{P}$ and lipid $\mathrm{P}$ showed a similar change with RNA-P.

4) Phosphoprotein was not found through all the stages.

\section{緒}

分娩発来機序解明の一環の実験として，先に，妊娠経 過の進行と共に 増加するラット子宮筋重量及び 子宮筋 actomyosin 量について発表した1). 今回は，てれらの実

\section{言}

験を更に進め, 蛋白合成に関与する燐酸化合物, 特に核 酸を中心として, 子宮筋内燐酸化合物の変動を, 妊娠経 過と共に観察したので，その成績を報告する。
\end{abstract}

\section{実験材料及び実験方法}

1. 材料：体重約 $150 \mathrm{~g}$ の成熟処女ラットを交配, 妊娠させ, 非妊時, 妊娠 11 日目, 18 日目, 産裖第 1 日 目, 4 日目, 10 日目, 離乳 2 日目 (産褶 12 日目), 離乳 5 日目（産裖 15 日目）に断頭潟血した後, 開腹して子宮 を摘出した，摘出した子宮より，胎盤胎览等を除き，無 灰瀘紙で血液を充分除去した後, 科量し，直ちに実験に 供した。

2. 総燐の定量 : 電気炉中で $300^{\circ} \mathrm{C}, 48$ 時間乾性灰

$$
\text { 実 験 成 }
$$

\section{1. 総 燐 量}

結果は図 1 に示す如くである. 数值は乾燥重量 $1 \mathrm{~g}$ 当 りの含有量である・
化し，N/10-HCl に溶解し，その溶液について FiskeSubbarow 氏法2) で比色定量した。

\section{3. 燐酸化合物分画法}

Schmidt \& Thannhäuser 氏法 ${ }^{3)}$ で, 酸溶性燐, 燐脂 質, 燐蛋白質, DNA, RNA を分画し, 各々の無機燐は Fiske-Subbarow 氏法, Youngburg-Youngburg 氏法4)， 又は，赤松一今井氏法5),6)により定量した。

\section{成 績}

総燐量として観察すると, 子宮筋内に於ては, 全時期 を通じて大差を示さなかった. 即ち, 非妊時 $1.79 \mathrm{mg} / \mathrm{g}$, 妊娠 10 日目 $1.87 \mathrm{mg} / \mathrm{g}$, 妊娠 12 日目 $1.65 \mathrm{mg} / \mathrm{g}$, 妊娠 


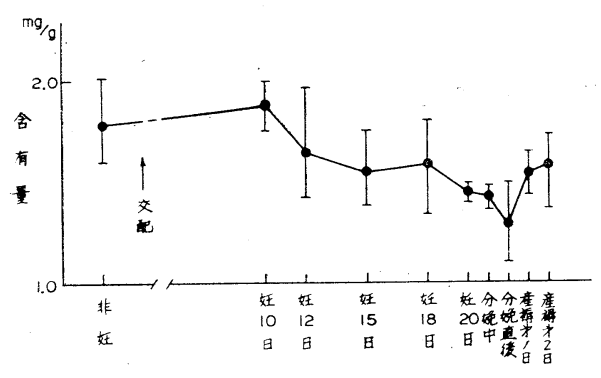

図 1. Rat 子宮筋内総蹸量

15 日目 $1.55 \mathrm{mg} / \mathrm{g}$ ，妊娠 18 日目 $1.59 \mathrm{mg} / \mathrm{g}$, 妊娠 20 日 目 $1.45 \mathrm{mg} / \mathrm{g}$, 分娩中 $1.42 \mathrm{mg} / \mathrm{g}$, 分娩直後 $1.36 \mathrm{mg} / \mathrm{g}$, 分婏後 24 時間 $1.56 \mathrm{mg} / \mathrm{g}$, 分婏 48 時間 $1.58 \mathrm{mg} / \mathrm{g}$ であ った。

\section{DNA, RNA 量}

結果は表 1, 図 2 に示す如くである.

数值は acetone powder $1 \mathrm{~g}$ 当りの含有量である. DNA-P 量は, 図 2 に示す如く, 非妊時は $946 \gamma / g$, 妊 娠 11 日目 $1177 \gamma / \mathrm{g}$, 妊娠 18 日目 $1540 \gamma / \mathrm{g}$, 産褯時は, 1 日，4日，10日，12日，15日と各々 $1637 \gamma / g ， 1456 \gamma / g ，$ $1595 \gamma / \mathrm{g}, 1617 \gamma / \mathrm{g}, 1552 \gamma / \mathrm{g}$ で妊娠末期まで漸次増加 し, 以後大体不変である. RNA-P 量は, 図に示す如 く, 非妊時 $1044 \gamma / \mathrm{g}$, 妊娠 11 日目 $1660 \gamma / \mathrm{g}$, 妊娠 18 日 目 $2607 \gamma / \mathrm{g}$, 産裖時 1 日， 4 日，10日，12日，15日子 各々 $1793 \gamma / \mathrm{g}, 309 \gamma / \mathrm{g}, 375 \gamma / \mathrm{g}, 543 \gamma / \mathrm{g}, 708 \gamma / \mathrm{g}$ で, 妊娠末期に最大となり，分婏終了と共に激減し，産裖 4 日を境として漸次, 旧に復する.

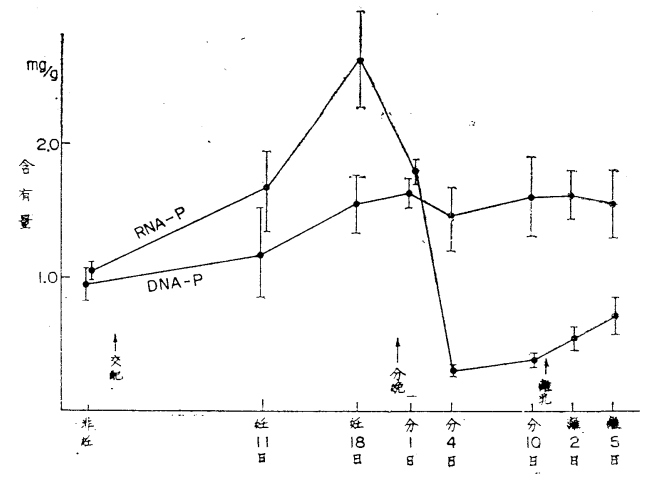

図 2. Rat 子宮筋内核酸量

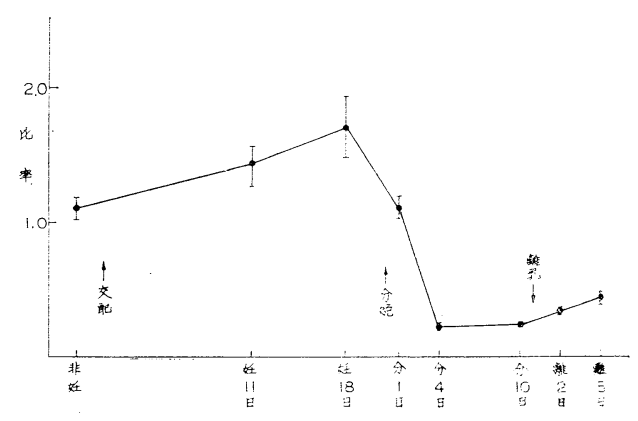

図 3. Rat 子喜 RNA-P/DNA-P

\section{RNA-P/DNA-P}

結果は図 3 に示す如くである.

RNA-P/DNA-P 值は, 妊娠進行と共に増加し, 妊娠 末期で最大となり, 分婏と共に著減し, 泌乳4日目で最

表 1. Rat 子宮筋内核酸量 単位 $\gamma / \mathrm{g}$ (acetone powder)

\begin{tabular}{|c|c|c|c|c|c|c|c|}
\hline & RNA-P & DNA-P & $\begin{array}{l}\text { RNA-P } \\
\text { DNA-P }\end{array}$ & & RNA-P & DNA-P & $\begin{array}{l}\text { RNA-P } \\
\text { DNA-P }\end{array}$ \\
\hline 非 & $\begin{array}{r}1032 \\
980 \\
1120\end{array}$ & $\begin{array}{r}928 \\
830 \\
1080\end{array}$ & $\begin{array}{l}1.11 \\
1.18 \\
1.02\end{array}$ & \multirow{2}{*}{ 分 } & $\begin{array}{l}336 \\
265 \\
325\end{array}$ & $\begin{array}{l}1664 \\
1125 \\
1580\end{array}$ & $\begin{array}{l}0.21 \\
0.24 \\
0.21\end{array}$ \\
\hline 妪 & 1044 & 946 & 1.10 & & 309 & 1456 & 0.22 \\
\hline 娃 & $\begin{array}{l}1340 \\
1930 \\
1710\end{array}$ & $\begin{array}{r}860 \\
1520 \\
1150\end{array}$ & $\begin{array}{l}1.56 \\
1.27 \\
1.48\end{array}$ & 分 & $\begin{array}{l}327 \\
417 \\
380\end{array}$ & $\begin{array}{l}1313 \\
1793 \\
1680\end{array}$ & $\begin{array}{l}0.25 \\
0.23 \\
0.23\end{array}$ \\
\hline 11 & 1660 & 1177 & 1.44 & 10 & 375 & 1595 & 0.24 \\
\hline 妊 & $\begin{array}{l}2260 \\
2970 \\
2590\end{array}$ & $\begin{array}{l}1530 \\
1760 \\
1340\end{array}$ & $\begin{array}{l}1.48 \\
1.69 \\
1.93\end{array}$ & 離 & $\begin{array}{l}590 \\
630 \\
459\end{array}$ & $\begin{array}{l}1610 \\
1800 \\
1440\end{array}$ & $\begin{array}{l}0.37 \\
0.35 \\
0.32\end{array}$ \\
\hline 18 & 2607 & 1544 & 1.70 & 2 & 543 & 1617 & 0.35 \\
\hline 分 & $\begin{array}{l}1840 \\
1820 \\
1690\end{array}$ & $\begin{array}{l}1740 \\
1530 \\
1640\end{array}$ & $\begin{array}{l}1.06 \\
1.19 \\
1.03\end{array}$ & 離 & $\begin{array}{l}855 \\
590 \\
680\end{array}$ & $\begin{array}{l}1780 \\
1300 \\
1575\end{array}$ & $\begin{array}{l}0.48 \\
0.45 \\
0.39\end{array}$ \\
\hline 1 & 1793 & 1637 & 1.10 & 5 & 708 & 1552 & 0.44 \\
\hline
\end{tabular}


低值となり, 泌乳 10 日目も同值を示した。離乳後 2 日 目, 即ち, 産裷 12 日目より增加し始为, 次第に非妊時 值に回復した。

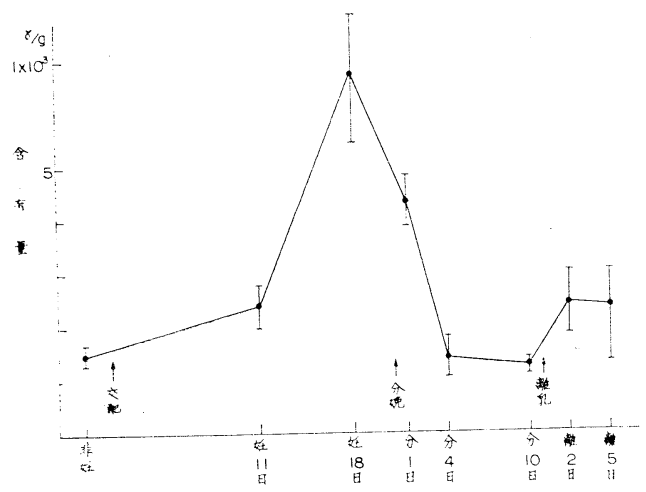

図 4. Rat 子宮内酸溶性燐

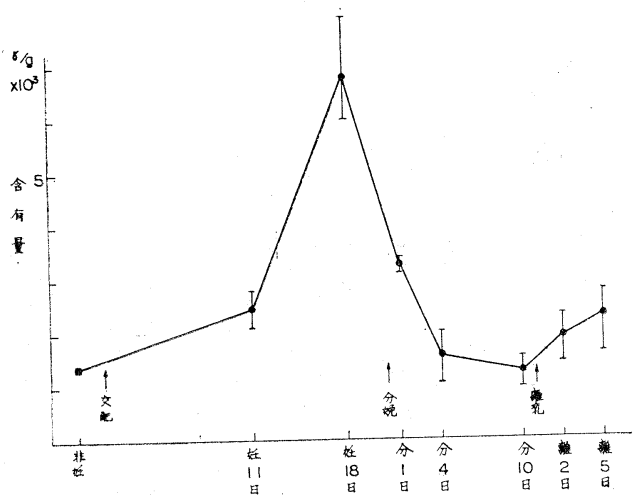

図 5. Rat 子宮内燐脂質

考

この実験の成績を考按するに際し，先ず，数量の基準 そついて考えると，妊娠，分娩による子宮の変化が著し い。即ち，卵巣ホルモンによる水分代謝が生鮮重量に及 ぼす影響を考えれば, 生鮮組織量を基準にとるととは不 適当である. 従って，ててでは脱脂乾燥末 (acetone powder) について実験を行った。総燐は全体として各期 により著変を示さなかった・てれは，子宮全体に含有さ れている燐量により生理的問題を検討するととの不可で あるととを示している. DNA 及び RNA 量は妊娠の経 過と共に増加を示した. 子宮に於ける核酸の態度は, 誠 に妊娠, 分婏の経過を如実に表現している. 妊娠と共に 起る急激な子宮の増大は, DNA, RNA の変化に直ちに 反映し，分婏による急激な子宮の縮小が， RNA の変化 として表われている. 妊娠進行と共に増加するDNA 量 の増加は，子宮に於ける細胞の増加を示し， RNA 量の

\section{4. 酸溶性燐}

結果は表 2, 図 4 亿示す如くである・

この物質は，RNA-P とはぼ同一傾向の変化を示し， 特に妊娠末期は著明な増加を示し, 離乳と共に旧に復し た。

\section{5. 燐 脂 質}

結果は表 2, 図 5 に示す如くである.

この物質も RNA-P 及び酸溶性燐と殆んど同一の傾 问を示し，離乳と共に旧值に復した。

\section{6. 燐蛋 白}

燐蛋白は全時期を通じて全く認められなかった。

表 2. Rat 子宮の酸溶性燐 (A.P.) と燐脂質 (L.P.)

\begin{tabular}{|c|c|c|c|c|c|}
\hline & A. P. & L. P. & & A.P. & L. P. \\
\hline 非 & $\begin{array}{l}1440 \\
1580 \\
1320\end{array}$ & $\begin{array}{l}1415 \\
1330 \\
1390\end{array}$ & \multirow{2}{*}{$\begin{array}{l}\text { 分 } \\
4\end{array}$} & $\begin{array}{l}1770 \\
1050 \\
1310\end{array}$ & $\begin{array}{l}2025 \\
2157 \\
1620\end{array}$ \\
\hline 妊 & 1447 & 1378 & & 1360 & 1567 \\
\hline 妊 & $\begin{array}{l}2750 \\
1960 \\
2480\end{array}$ & $\begin{array}{l}2100 \\
2780 \\
2350\end{array}$ & \multirow{2}{*}{$\begin{array}{l}\text { 分 } \\
10\end{array}$} & $\begin{array}{l}1080 \\
1380 \\
1290\end{array}$ & $\begin{array}{r}968 \\
1520 \\
1310\end{array}$ \\
\hline 11 & 2397 & 2410 & & 1250 & 1266 \\
\hline 妊 & $\begin{array}{l}5450 \\
7840 \\
6990\end{array}$ & $\begin{array}{l}5980 \\
7900 \\
6400\end{array}$ & \multirow{2}{*}{$\begin{array}{l}\text { 離 } \\
2 \\
2\end{array}$} & $\begin{array}{l}1820 \\
2980 \\
2240\end{array}$ & $\begin{array}{l}1436 \\
2310 \\
1920\end{array}$ \\
\hline 18 & 6660 & 6760 & & 2347 & 1889 \\
\hline 分 & $\begin{array}{l}4820 \\
3850 \\
4250\end{array}$ & $\begin{array}{l}3120 \\
3398 \\
3280\end{array}$ & \multirow{2}{*}{$\begin{array}{l}\text { 離 } \\
5 \\
5\end{array}$} & $\begin{array}{l}2980 \\
1290 \\
2680\end{array}$ & $\begin{array}{l}2770 \\
1600 \\
2540\end{array}$ \\
\hline 1 & 4307 & 3266 & & 2317 & 2304 \\
\hline
\end{tabular}

按

増加は筋細胞内に於ける蛋白合成が盛んなととを示して いる. 即ち, 弤娠子宮筋の増大は, 筋細胞の増加之筋細 胞内蛋白質の増加の両面より行なわれているととを示す ものである.なぜならば，DNA は普通の場合，細胞核 にのみ見出され，細胞核の中では染色体の上にのみ分布 するものである．DNA が遺伝現象に重要な役割を果す ものであるというととは別として，細胞核当りの DNA 量は生物でとに一定で，同じ生物なら組織が異っても同 ビで，外的環境条件などによって左右されず，一定した ものである.生物が飢餓状態などにおかれて，たとえ他 の細胞成分には増減があっても, 細胞当りの DNA 量だ けは増減がないとされている。とのととより，DNA 量 が増加しているというととは，子宮内細胞の増加を示し ているととになる. 又, RNA については，DNA から 情報が RNA に流され，乙れが一種の鋳型となって特定 
の構造をもった蛋白質が合成されると考えられている. そとで，生体内の蛋白質の合成というととに RNA の 重要な機能を認めるのである. RNA は機能的には一種 類ではなく，同じ蛋白合成を行う場合にあっても $\mathrm{S}$ RNA, メッセンジャーRNA, リボゾーム RNA という ように，それぞれ異った作用を分担している．てのよう に，蛋白質が合成されるからくりは，可成，巧妙に出来 ているてとが次第に明らかになって来つつあるが，古く から考えられているような，RNA が蛋白質の鋳型にな るということは間違っていないようである7),8). このと とから, RNA が妊娠進行と共に増大するという事実は, 細胞の増加と共に，一細胞単位としてみた場合でも蛋白 質増加が著明であるととを示すものである.とてで RNA-P/DNA-P の比が，非妊時より妊娠 11 日目，11 日目より妊娠末期の方が次第に大となるととは, 妊娠進 行と共に蛋白質合成がより活発になるととを示し，分婏 後は，蛋白質合成は急激に不活発になり，泌乳 4 日より

\section{結}

妊娠，産裖各期のラット子宮筋内燐酸化合物を測定 し, 次の結果を得た。

1) RNA-P は妊娠末期に最大值を示し, 分婏終了と 共に激減し，産裖 10 日頃より再び旧に復し始める.

2) DNA-P は妊娠末期まで増加するが，以後大体不 変である.

3) RNA-P/DNA-P は妊娠進行と共に増大し, 分婏 と共に減少, 離乳と共に再び旧に復し始める.

\section{文}

1) 藤井, 加藤, 杉山：第 13 回日本産科婦人科学会 総会発表. 昭和 36 年 3 月.

2) Fiske, C.H. \& Subbarow, Y.: The colorimetric determination of phosphorus. J. Biol. Chem., 66, 375, 1925.

3) Schmidt, G. \& Thannhauser, S. J. : A method for the determination of desoxyribonucleic acid, ribonucleic acid, and phosphoproteins in animal tissues. J. Biol. Chem., 161, 83, 1945 .
10 日にかけて最低值となることは, 泌乳時には子宮での 蛋白質合成作用が最低であることを示している．こてで 離乳すると卵巣ホルモンが活動し始めるととにより，再 び蛋白質合成が活発化するてとは，子宮が再び正常状態 に戻り始めたてとを示すものである. 分婏時に妊娠末期 よりむしろ RNA-P 量が減少するてとは, 分婏という子 宮収縮による巨大なエネルギー消耗というととを考える と, RNA-P がより増加していてもよいようであるが、 収縮は蛋白質合成に関係なく, 種々のホルモンの平衡変 動が，子宮筋の環境状態に影響を及ぼして子宮収縮を起 すと考えられるから，RNA-P が増加しなくても別に不 思議はない，とのように子宮の核酸の増減は, 妊娠分娩 という物理的変化と完全に一致している. 酸溶性燐や燐 脂質が， RNA-P 值と同一傾向を示しつつ遂移すると之 は，RNA-P の燐がてれらの物質より取り入れられるの ではないかと推考出来る。乳汁中に存在する特殊な蛋白 質である燐蛋白は全く認められなかった。

\section{語}

4) 酸溶性燐, 燐脂質は RNA-P と同一傾向の変化 を示す.

5）燐蛋白は全期に於て認められない.

擱筆するに際し, 終始御懇篤な御指導, 御校閲を賜った 井久四郎教授に謹しんで感謝の意を捧げます，尚，本論文 の要旨は第 15 回日本産科婦人科学会総会, 第 114 回日本産 科婦人科学会東京地方部会において発表した.

\section{献}

4) Youngburg, G.E. \& Youngburg, M.V.: Phosphorus metabolism. J. Lab. Clin. Med., 16, 158, 1930.

5) Akamatsu, S.: Some micromethods for enzyme studies. J. Biochem., 39, 203, 1952.

6) Imai, K. : Microanalysis of blood phosphorus. J. Jap. Biochem. Soc., 20, 18, 1948.

7) 三浦謹一郎：核酸の化学, 東京化学同人, 1963.

8) Davidson, J.N. :The Biochemistry of Nucleic Acids, Methuen \& Co.; London, 1960. 